"Customary versus Technological Advancement Tests »

\author{
$\underline{\text { Auteurs }}$ \\ Bruno DEFFAINS \\ Dominique DEMOUGIN \\ Document de travail $n^{\circ}$ 2006-12
}

Avril 2006

Faculté des sciences économiques et de gestion Pôle européen de gestion et d'économie (PEGE) 61 avenue de la Forêt Noire F-67085 Strasbourg Cedex

Secrétariat du BETA Christine Demange Tél. : (33) 0390242069 Fax : (33) 0390242070 demange@cournot.u-strasbg.fr http://cournot.u-strasbg.fr/beta 


\title{
Customary versus Technological Advancement Tests
}

\author{
Bruno Deffains*and Dominique Demougin ${ }^{\dagger}$
}

This version: January, 2006

\begin{abstract}
In an environment where the optimal level of care is unknown, we ask under a state of the art defense which method is better able to induce parties to undertake optimal care. Assuming courts can see a noisy signal of research activities undertaken by a defendant and some of its competitors, we ask whether courts should use a biased or unbiased average to compare care. We find that the later is better.
\end{abstract}

KEYWORDS: Tort law, standard of care, customary test, technological advancement test

JEL Classification: K13

\section{Introduction}

It is well known that, over the course of the last century, producers'liability has become an important topic in most developed economies. The economic justifications for the evolution of producer tort are numerous and well documented. From a positive perspective, the products sophistication has been advanced by Landes and Posner (1987) as well as the ability of the consumer to be correctly informed on the risk of accident (Spence, 1977; Viscusi and

*Deffains: Faculty of Law and Economics, 25 rue Baron Louis, University of Nancy 2, Nancy, France, Tel: + 333831926 52, Bruno.Deffains@univ-nancy2.fr.

${ }^{\dagger}$ Demougin: School of Business and Economics, Humboldt University at Berlin, Spandauer Str. 1, D-10178 Berlin, Germany, Tel: +49 30 2093-1342, Fax: +49 30 2093-1343, demougin@wiwi.hu-berlin.de. 
Moore, 1993). Law and economics scholars have also argued about the excessive activity level under a negligence rule (Polinsky and Shavell, 1980; Landes and Posner, 1981; Calfee and Craswell, 1986). Moreover, from the point of view of legal theory, some authors propose to ground producer liability on the risk represented by the consumption of products rather than on the behavior of the producers (for a general discussion see Hylton, 2001). In the same way, the second part of the 20th century has been characterized by a growing acceptance of the notion that more extensive tort liability would serve to compensate parties as an insurance mechanism.

Nevertheless some issues remain controversial. One such question is whether and, if yes, under which circumstances a producer might be able to defend himself. The purpose of this article is to explore the welfare characteristics of a defense based on a state of the art argument.

To fix ideas, consider the following fictitious example of assessing the liability of a producer. A pharmaceutical firm designed and marketed a medication to reduce cholesterol levels. Fifteen years later, a researcher team discovered that this particular medication increases the likelihood of cancer. Suppose now that the firm is brought to court by a widow who's husband was treated with the medication and later on died of a cancer. Should, in this example, the full extend of strict liability apply or should courts allow for the possibility of a defense. Indeed, the firm might have been extremely conscientious in doing its research and included all the scientific knowledge available at the time. In such a case, it would appear questionable whether to make the pharmaceutical firm liable is economically and logically sound. Indeed, instead of increasing producers' care, one would think it could well reduce overall research activities?

Some authors have pointed out such a possible drawback suggesting that "a broad and unpredictable sweep of liability" could deter innovation. For example, Porter (1990) states that product liability in the United States is so extreme and uncertain as to retard innovation, it places firms in constant jeopardy of costly and, as importantly, lengthy product liability suits. He finds the risk of lawsuits is so great, and the consequences so potentially disastrous, that the inevitable result is more caution in product innovation than in other advanced nations.

Others come to the opposite conclusion, finding that authorizing any form of defense in a producer liability case undermines the strict nature of the liability rule and must, consequently, be rejected. For example, in Cunningham v. MacNeal Memorial Hospital, the Illinois Supreme Court rejected the argument that blood products then in use complied with the state-of-the-art in terms of safety from hepatitis contamination. The Court stated that "to allow a defense to strict liability on the ground that there 
is no way, either practical or theoretical, for a defendant to ascertain the existence of impurities ... would emasculate the doctrine ... and signal a return to a negligence theory" (Cunningham v. Memorial Hosp. 266 N.E.2d 897 at $902(1970))$.

In practice, most judicial systems permit some defense based on a state of the art argument. For example, the US the restatement Second of Tort $\S$ 402 A (1965) defining the products liability principles, permits such a defense requiring a "demonstration that the technology available for the manufacture of a safer finished product with the same characteristics was not feasible". For the EU, the council directive 85/374/EEC concerning the liability for defective products states in article 6 that in order to determine whether a "product is defective" requires "taking all circumstances into account, including .. (c) the time when the product was put into circulation." Moreover, article 7 states that a "producer shall not be liable as a result of this directive if he proves ...(e) that the state of scientific and technical knowledge at the time when he put the product into circulation was not such as to enable the existence of the defect to be discovered." With some delay, this directive has been implemented in the legislation of most the EU member states.

However, as we documented with the Cunningham v. MacNeal Memorial Hospital case, the state of the art defense remains controversial. Moreover, its application raises numerous questions. For instance, when specifically should the defense be applied. In the case O'Brien v. Muskin Corp., the New Jersey Supreme Court, while recognizing the value of evidence as to the state-of-the-art in determining product defect and in applying a risk-utility analysis, held that the defense is not absolute (O'Brien v. Muskin Corp., 463 A.2d, 306 (N.J. 1983). Further, in Beshada v. Johns Manville, the New Jersey Supreme Court expressly disallowed the state-of-the-art defense to the issue of failure to warn (Beshada v. Johns-Manville Corp., 447 A 2d 539 (N.J. 1982).

The foregoing naturally leads to the question as to when a court should deem a defense of "state of the art" to be reasonable and when it should conclude that a defendant was liable. In practice, product liability cases usually focus on competing experts debating whether the design of the product is sufficiently safe. Not surprisingly, a standard argument brought forward by defense lawyers is that the product of their client and the safety thereof is very similar to competing products by other manufacturers.

In this respect, Boyd and Ingberman (1997) suggest two different approaches to this line of this defense. According to the first one, firms should avoid liability if at time of production the safety of their production process compared favorably to the customary practices in the industry. With this interpretation, the state of the art defense is a customary practice test, i.e. a 
relative test of liability (rather than absolute one) that is almost exclusively designed on a comparison between the characteristics of the defendant's production process and the characteristics of its competitors' process. According to the second interpretation, state of the art should only refer to a more exceptional safety level. This could be interpreted as demanding of the defendant to have been at the forefront of technical advancement or capability. Following Boyd and Ingberman (1997), we refer to this second criterion as the technologically advancement test.

With the first definition, a state of the art production process is one which conforms to the customary practice of the industry. Under the second, simply conforming with custom directly invalidate a state of the art defense. It holds defendant to a more stringent test than conformance with industry custom. It does not require of the defendant to have the safest technology, but to be significantly better than the average. ${ }^{1}$

Put in the context of the economic literature, the state of the art defense suggests a form of ex-post contest/tournament (see e.g. Lazear and Rosen, 1981) where the safety procedure of the defending firm is compared with a measure of the average practice from a pool of other firms engaged in the same activity. At the time of research, development and production firms are thought to anticipate what would happen in the case of accident. Consequently, the ex post contest generates an incentive for undertaking safety activities. In terms of game theory, the state of the art defense induces a Nash equilibrium in the level of care.

In some respects, our approach is reminiscent of the analysis of the negligence rule. In a way, it constitutes a new way to analyze the functioning of liability rules. Usually, when one consider the definition of a standard of care, it refers to an absolute level of care (for example the bonus pater familias or the Hand formula). Here, our approach combines a traditional model of tort liabitity with a rent seeking elements : firms engage in a quasi-rent-seeking contest in which the higher the level compared to the other players, the lower the expected liability $\operatorname{costs}^{2}$. This contest is however expensive as the judicial

\footnotetext{
${ }^{1}$ In practice, with the two tests, it could be possible to consider that liability is not completely removed when all firms have the same technology. Instead, when all firms seem identically safe, there is a probability that a plaintiff can successfully argue that this customary practice in the industry is, in fact, unreasonably unsafe. This explains why a "race to the bottom" is not a convincing equilibrium as long as courts impose a reasonableness test on the industry custom. The definition of a minimum standard by the regulator can also contribute to control the strategy of the firms.

${ }^{2}$ In a way, the standard is defined in relative terms: when firms face a state of the art defense, they perceive that they can influence the standard defined by the courts and so, that the standard becomes endogenous. This is true with a customary practice test as well as with a technological advancement test.
} 
system needs to determine the number of players to consider, the nature of the state of the art defense, to determine by sample analysis the average level of care and to establish liability individual cases.

With this terminology in mind, the question of the appropriate state of the art defense can be reformulated as to whether the contest should be "fair" or "biased". The question can be generalized; is there a contest that is universally optimal or should the state of the art defense depend on some characteristics of the case? If it should depend on characteristics of the case, what is the dependence? For example, in some cases courts will be able to compare the firm's behavior to a large pool of other firms. In other situations, perhaps because evaluating care is extremely costly, the pool will be much smaller. Should this affect the way state of the art defense is implemented by courts? For example, should the choice between a "technological advancement" and "customary practice" test depend on the sample size to which the defendant is compared to? If so, in which way? A second obvious issue is the level of damage. Our first intuition would suggest that as damages increase courts should, if anything, increase the bias to provide additional incentives since the efficient level of care has been raised. Surprisingly, the intuition is not necessarily correct. We derive other unexpected results. For example, we show that the optimal bias may be negative, i.e. an efficient state of the art defense may compare a firm's safety level with that of other firms and declare the firm non liable even if it produced only $90 \%$ of the safety of other firms.

To analyze the issue ${ }^{3}$, we consider an industry with a large number of firms all involved in a similar type of research and development project. ${ }^{4}$ In the case of an accident and ensuing liability suit, courts are assumed to see a noisy signal of the defendant's care expenditure and similar signals for a number of competing firms. We then assume that courts can decide on allocation of damages by comparing these signals. We ask how the court showed best proceed, in particular, whether the comparison should be biased or not and if so in which direction.

The remainder of the paper is structured as follows. Next section introduces a model. Section three derives the main result. Section four develops and discusses comparative static results. The last section offers some con-

\footnotetext{
${ }^{3}$ Notice that our analysis in normative given the fact that courts have to apply a state of the art defense. Whatever the liability system is with or without fault is not the problem. Of course, as most of countries have currently a system of strict product liability, the model consider the conditions of application of the defense under this regime.

${ }^{4}$ The reason for assuming a large number of firms is just to avoid a cooperative agreement by the firms to keep the level of care low, thereby "forcing" them to play non cooperatively.
} 
cluding remarks.

\section{The model}

We consider a market with a large number of identical firms all undertaking a similar research and development project leading to the marketing of a new product. We denote by $c$ the firm's expenditures of designing and developing the product safely. Slightly abusing terminology, we refer to these expenditures hereafter as the level of care undertaken by the firm. Given care, we denote by $p(c)$ the probability of accident, with $p^{\prime}(c)<0$ and $p^{\prime \prime}(c)>0$.

We assume that in the case of an accident the victim suffers the monetary equivalent of a damage $L$. We assume that $L$ and the function $p(c)$ are known to the firms at the time of decision. In the case of an accident, the court sees the damage $L$. However, in line with the objective of the paper and unlike in the standard literature about liability rules, we assume that the court does not evaluate by itself the level of due care ${ }^{5}$. It rather estimates what the firm should have done by comparing its behavior to some of its competitors.

In the case of an accident by firm $i$, the court can see a noisy signal of the level of care undertaken by the firm. Specifically, we assume that the court sees the monetary signal, $x_{i}=c_{i}+\varepsilon_{i}$, of the firm's research expenditure. ${ }^{6}$ For the sake of comparison, the court also collects additional information on the research behavior of the firms. Specifically, we assume the court sees a vector $\left(x_{i 1}, \ldots, x_{i N}\right)$ where each of variable $x_{i j}=c_{i j}+\varepsilon_{i j}, j=1, . . N$ are similar monetary signals of the research expenditure undertaken by the firms $i j$. In the remaining $N$ will play a significant role. It denotes the sample size of firms with which the defendant will be compared to. More generally, it stands for the precision or the accuracy which the court will expect of its experts. From the point of view of the judicial system, $N$ is a choice variable; either it could be externally determined through a legal rule, or left to the judge's discretion.

We consider that the error terms in the respective signals are all identically, independently and symmetrically distributed around their mean. More-

\footnotetext{
${ }^{5}$ It is interesting to note that the benchmark where all the $c$ are observervable (or when the risk of error converges to zero) cannot be considered as a good representation of reality. Following Boyd and Ingberman (1997), it leads to a knife-edge result : if $\Delta$ is positive, the technological advancement test yelds excesive safety expenditure. If $\Delta \leq 0$, the "customry practice test creates a race to the bottom in which the equilibrium is to spend nothing on safety" (Boyd and Ingberman, p. 459).

${ }^{6}$ The justification of this assumption is that even though courts and experts can observe a firm's accounts records, the firm can and will most likely use creative book keeping to shift expenditures to its advantage, thereby biasing records.
} 
over, we assume that given $c$, the error term is independent of the likelihood of an accident (i.e. changes in $c$ only shift the mean of the distribution of the $x$ signals, but otherwise leaves the shape of the density functions unaffected). We do not make any assumption regarding the expected value of the $\varepsilon^{\prime}$ s, except that they be identical across firms. Though, in general one would expect the mean to be positive simply because firms should be interested to inflate their reporting on safety. ${ }^{7}$ We denote by $\bar{X}_{i}$ the average over the vector $\left(x_{i 1}, \ldots, x_{i N}\right)$.

To model the state of the art defense, we suppose that in the case of a lawsuit in the environment described above, courts are asked to compare $x_{i}$ and $\bar{X}_{i}$, rejecting the defense of state of the art, i.e. finding the defending firm liable, if $x_{i} \leq \bar{X}_{i}+\Delta .^{8}$ The interpretation of $\Delta$ is that it captures whether society should expect the defendant to have produced an exceptional effort ( $\Delta$ large, i.e. the court is using a technological advancement test) or simply to have conformed to the customary practice of the industry (i.e. $\Delta=0$ ).

\section{The firm's decision problem}

Assuming that the firms in the market under consideration understand the behavior of courts and, in particular, the application of the liability rule with a state of the art defense, their choice regarding research and development to improve safety can be represented as a minimization problem where they trade of care costs against expected damage payments. However, in the current problem of liability firms play (at least in expected value) a Nash game that implicitly defines, in case of an accident, whether they will succeed with a defense based on a state of the art argument.

Considering the usual practice in civil liability systems, payments made by the defendant, if he fails with the state of the art defense and is, therefore, found liable, is assumed equal to the incurred damage costs $L$. Thus, firm $i$ solves

$$
\min _{c} c+p(c) \operatorname{Prob}\left[x_{i} \leq \bar{X}_{i}+\Delta \mid c, \bar{C}\right] L,
$$

where $\operatorname{Prob}\left[x_{i} \leq \bar{X}_{i}+\Delta \mid c, \bar{C}\right]$ denotes the probability that a firm which caused a damage, $L$, fails with a defense based on the state of the art, given that its own care decision was $c$, the average care of the sampled firms which

\footnotetext{
${ }^{7}$ See footnote 6 .

${ }^{8}$ Keep in mind that even though in accordance with legal practice, we consider a strict liability rule with a state of the art defense, from an analytical point of view it is also possible to interpret the model in terms of negligence rule.
} 
was $\bar{C}$ and the legal interpretation of the state of the art defense characterized by $\Delta$.

We limit the analysis to the symmetric Nash equilibrium where all the firms find it optimal to undertake $c^{E}$, and thus $\bar{C}=c^{E}$. Given the foregoing distributional assumptions, the probability of a firm being found liable in the case of an accident becomes

$$
\operatorname{Prob}\left[x_{i} \leq \bar{X}_{i}+\Delta \mid c, c^{E}\right]=\operatorname{Prob}\left[\xi \leq c^{E}-c+\Delta\right],
$$

where $\xi=\varepsilon_{i}-\bar{\varepsilon}$. Denoting $\xi$ 's distribution by $F$ with $F^{\prime}=f$, we note that $f$ is by construction symmetrical. Moreover, $\xi$ 's expected value must zero In addition, we assume that $f$ is single peaked. For the remaining, it is important to note that the distribution of $\xi$ varies with the sample size $N$. For example, the relation $\sigma_{\xi}^{2}=\left(1+N^{-1}\right) \sigma_{\varepsilon}^{2}$ between the variance of $\xi$ and $\varepsilon$ is easily verified. Naturally, we find that the sample size of competitors to which the defendant is compared with reduces the variance of $\xi .^{9}$ finally, we assume that $F$ satisfies the MLRC property (i.e. $\frac{d}{d \xi}\left[\frac{f(\xi \mid N)}{1-F(\xi \mid N)}\right]>0$ ). ${ }^{10}$

Altogether, the firm's problem can be rewritten as

$$
\min _{c} C^{F}(c, \Delta, N)=c+p(c) F\left(c^{E}-c+\Delta \mid N\right) L
$$

where $C^{F}$ stands for the expected costs of the firm undertaking care $c$ in a judicial environment where the state of the art defense is characterized by $\Delta$ and $N$. The symmetric Nash equilibrium obtains precisely when $c^{E}$ is the solution of (3) for each firm. As a result, $c^{E}$ is implicitly defined by the first order condition of the firm's problem, i.e.: ${ }^{11}$

$$
1+\left[p^{\prime}\left(c^{E}\right) F(\Delta \mid N)-p\left(c^{E}\right) f(\Delta \mid N)\right] L=0
$$

The condition shows that just as one would expect the firms' behavior will react both to changes in $\Delta$ and $N$. In particular, implicitly differentiating yields:

$$
\frac{\partial c^{E}}{\partial \Delta}=-\frac{\left.\left(p^{\prime}\left(c^{E}\right) f(\Delta \mid N)-p\left(c^{E}\right) f^{\prime}(\Delta \mid N)\right]\right) L}{C_{c c}^{F}\left(c^{E}, \Delta, N\right)}
$$

\footnotetext{
${ }^{9}$ Geometrically, as the sample size increases, the ditribution of $\xi$ centers more and more around its mean. Note however that even with very large sample, the firm cannot avoid the risk created by its own error term $\varepsilon$.

${ }^{10}$ See Milgrom (1981).

${ }^{11}$ Observe that the second order condition of the firm's problem $\left(p^{\prime \prime} F-2 p^{\prime} f\right)+p f^{\prime}$ is always satisfied for $\Delta \leq 0$ (note that the terms in bracket are both positive). However, for some $\Delta>0$ the second order condition may not be satisfied. This limits the choices of $\Delta$.
} 
where $C_{c c}^{F}$ stands for the second order condition of the firm's problem. Since the firm is minimizing expected costs, $C_{c c}^{F}$ is necessarily positive. Consequently, for $\Delta \leq 0$, the Nash level of care $c^{E}$ is strictly increasing in $\Delta$. To see this, observe that for $\Delta \leq 0$, we have $f^{\prime}(\Delta \mid N)>0$. Moreover, $p^{\prime}\left(c^{E}\right)<0$ and $p\left(c^{E}\right), f(\Delta \mid N)>0$, thus in this case, $\frac{\partial c^{E}}{\partial \Delta}$ becomes positive.

What does this result suggests? Intuitively, unless courts bias the ex post contest, one would expect that with $\Delta=0$ the prisoner's dilemma implicit in the game between firms should induce them to underproduce care. To counteract this natural tendency, society should direct its courts to behave in such a way as to increase the safety produced by firms. In this respect, biasing the contest by demanding that firms' care be above the average may seem justifiable since according to (5) it would then increase care. Accordingly, it would appear that the appropriate definition of the state of the art defense should be in terms of an exceptional safety effort, therefore, requiring a technological advancement test (Boyd and Ingberman, 1997).

\section{The regulator's problem}

We reconsider here the above argument about the technological advancement test to counter the suggested under production of care. Though the above logic seems intuitively compelling, its heuristic is in fact erroneous. In order to detect the underlying inconsistency, observe that the parties do not minimize the true social costs $c+p(c) L$. Instead, firms minimize their own private cost $c+p(c) F(\bar{C}+\Delta-c) L$. This distortion has two effects. First, it has a level effect: by reducing the likelihood of paying for harm $-p(c) F(\bar{C}+\Delta-c)<p(c)$ - the firms underestimate expected damages. Second, it has a slope effect by changing the shape of the expected damage cost-curve. Our intuition captures the first effect (as Boyd and Ingberman!!!), thereby suggesting that firms should underproduce care. However, the second effect is determinant for the firm's care decision.

From the foregoing section, for the legal rule to have any impact, firms must anticipate the consequence of their choice on expected costs. Thus, the judicial system has to decide the characteristics of the state of the art defense and announce them. In our model, it requires to determine the bias level $\Delta$ and the sample size $N$.

In the following, we show that there are many ways to define the state of the art defense to implement first best care. To do so, we verify that there are many $(\Delta, N)$ combinations inducing firms to undertake the socially efficient care level as Nash equilibrium. Analytically, the first best solution is defined 
as the level of care that minimizes the true social costs, i.e.

$$
c^{*}=\min _{c} c+p(c) L
$$

Writing the first order condition of (6) and comparing it with (4) at the point $c^{E}=c^{*}$ yields:

$$
p^{\prime}\left(c^{*}\right)=p^{\prime}\left(c^{*}\right) F(\Delta \mid N)-p\left(c^{*}\right) f(\Delta \mid N)
$$

Therefore, any combination of $\Delta$ and $N$ that satisfies (7) will induce firms to produce the first best level of care at the Nash equilibrium. ${ }^{12}$ For a geometrical representation, it is useful to rewrite (7) in the following way

$$
\frac{-p^{\prime}\left(c^{*}\right)}{p\left(c^{*}\right)}=\frac{f(\Delta \mid N)}{1-F(\Delta \mid N)}
$$

In the figure $1, N$ is exogenously given. The upward sloping curve is the right hand side of (8). It is monotonically increasing due to the MLRC assumption. The left hand side of $(8)$ is positive due to $p^{\prime}<0$. In the case represented in the figure, a solution in $\Delta$ exists. ${ }^{13}$ Whether the two curves always intersect is a question of the characteristic of the distribution function. In the case of the exponential family, which includes all commonly used densities and in particular the normal distribution, the $\frac{f(\Delta \mid N)}{1-F(\Delta \mid N)}$-curve becomes unbounded as $\Delta \rightarrow+\infty$. In that case, existence is guaranteed. Moreover, given $N$, the solution is unique.

Changes in $N$ shift the $\frac{f(\Delta \mid N)}{1-F(\Delta \mid N)}$-curve affecting the optimal bias. Consequently, there are many pairs $\left(\Delta^{*}(N), N\right)$ that implement the first best. This suggests that the question as to whether or not the customary or the technological advancement test should be used to implement optimal care may, in fact, be the wrong question. For example, depending on the specific of the context, it is possible that both test can accomplish the task. However each of the tests will demand a different sample size. Moreover, as we will now discuss other tests may also work.

In the foregoing, we identified the customary test with $\Delta=0$. It will realize the first best if the sample size, hereafter denoted by $N^{*}$, satisfies: ${ }^{14}$

$$
\frac{-p^{\prime}\left(c^{*}\right)}{p\left(c^{*}\right)}=\frac{f\left(0 \mid N^{*}\right)}{1-F\left(0 \mid N^{*}\right)}
$$

\footnotetext{
${ }^{12}$ Assuming the second order condition holds. See the restrictions in footnote 11.

${ }^{13}$ Obviously assuming the second order condition holds.

${ }^{14}$ Observe that with $\Delta=0$, the second order condition is certainly satisfied.
} 


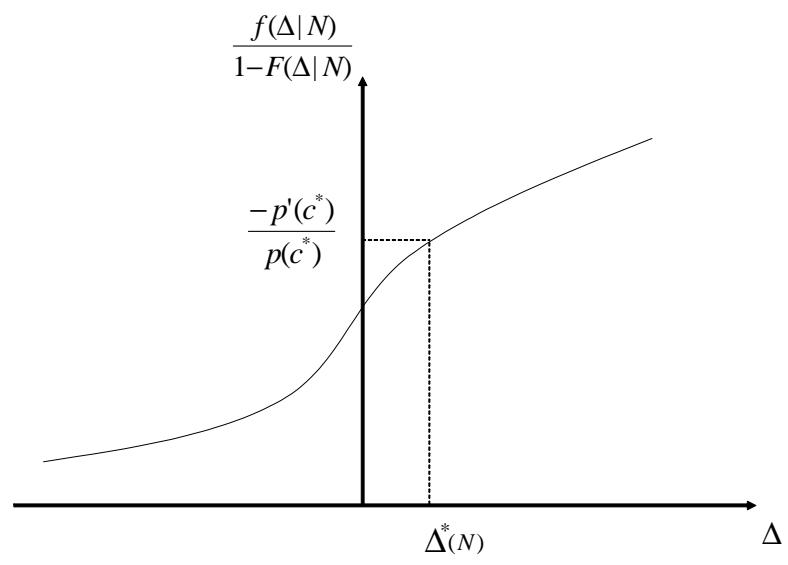

Keeping in mind that the distribution of the $\xi$ is symmetrical around zero, $F(0 \mid N)=1 / 2$ for all $N$. Therefore, the right hand side of (9) simplifies to $2 f\left(0 \mid N^{*}\right)$. Whether the equation has a solution in $N$ depends on the exact nature of the $\xi$ distribution. For example, if the underlying $\varepsilon$ are normally distributed, it is easily verified that (9) becomes

$$
\frac{-p^{\prime}\left(c^{*}\right)}{p\left(c^{*}\right)}=\frac{\sqrt{2}}{\sigma \sqrt{\pi\left(1+\frac{1}{N^{*}}\right)}}
$$

Since for all $N, 0 \leq \frac{1}{N} \leq 1,(10)$ has a solution provided that the condition

$$
\frac{1}{\sigma \sqrt{\pi}} \leq \frac{-p^{\prime}\left(c^{*}\right)}{p\left(c^{*}\right)} \leq \frac{\sqrt{2}}{\sigma \sqrt{\pi}}
$$

is satisfied. Assuming the above condition is satisfied, a customary test with sample size $N^{*}$ would implement the first best.

Naturally a question arises as to whether a technologically advancement test would also induce first best at te Nash equilibrium. To discuss the issue, consider decreasing $N$ below $N^{*}$. For $\Delta=0$, note that $f(0 \mid N)<$ $f\left(0 \mid N^{*}\right)$ (see equation (10)). Therefore the $\frac{f(\Delta \mid N)}{1-F(\Delta \mid N)}$-curve intersects the $y$ axes below the $\frac{f\left(\Delta \mid N^{*}\right)}{1-F\left(\Delta \mid N^{*}\right)}$-curve. Consequently, lowering the sample size below $N^{*}$ would require of courts to use a technological advancement test in order to implement the first best (see figure 4$)^{15}$.

\footnotetext{
${ }^{15}$ In the foregoing, the second order condition is ignored. As we discussed earlier this may limit the size of the feasible $\Delta$ and indirectly may provide a lower bound for feasible sample sizes.
} 


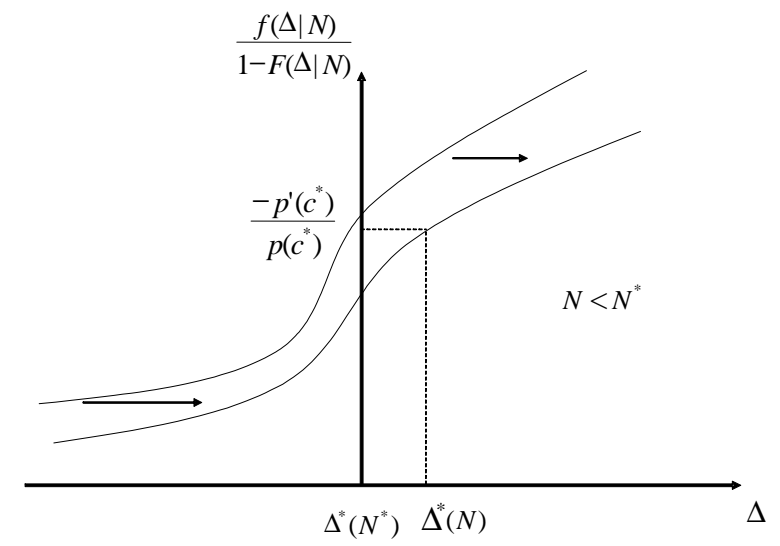

There is another way to understand the result. $N^{*}$ was originally defined to satisfy the firm's first order condition with $\Delta$ set at 0 :

$$
1+\left[p^{\prime}\left(c^{*}\right) F\left(0 \mid N^{*}\right)-p\left(c^{*}\right) f\left(0 \mid N^{*}\right)\right] L=0
$$

Consider an increase in $N$ above $N^{*}$ in (12). Observe that the first term in the square bracket remains unchanged since $F(0 \mid N)=1 / 2$ for all $N$. However, the second term drops, so that the left hand side of (12) becomes negative. This in turn implies that a firm facing a legal rule characterized by $\Delta=0$ and $N>N^{*}$ would find it optimal to increase its care level. Finally, note that $c^{*}+p\left(c^{*}\right) f(0 \mid N) L$ is constant for all $N$. Thus the two cost curves must intersect at $c^{*}$ as in figure 3 .

The observation points to a surprising peculiarity for legal policy. Suppose that instead of reducing $N$ below $N^{*}$, we were to consider an increase in the sample size. Again, this would shift the $\frac{f(\Delta \mid N)}{1-F(\Delta \mid N)}$-curve. However, now the curve would intersect the $y$-axes above the $\frac{f\left(\Delta \mid N^{*}\right)}{1-F\left(\Delta \mid N^{*}\right)}$-curve. Therefore, implementing the first best would require to set $\Delta<0$. In words, the megal rule would demand of courts not declare the defendant liable even if the comparison with the large sample was (marginaly) unfavourable to him.

The literature with respect to the state of the art defense has focused on the comparison between the customary practice test and the technologically advancement test. In doing so, it has neglected an important dimension. Indeed, for the comparison to be meaningfull, it must include a discussion on the sample size associated with the respective tests. The analysis shows that there is a trade-off between the bias introduced by the courts to establish 


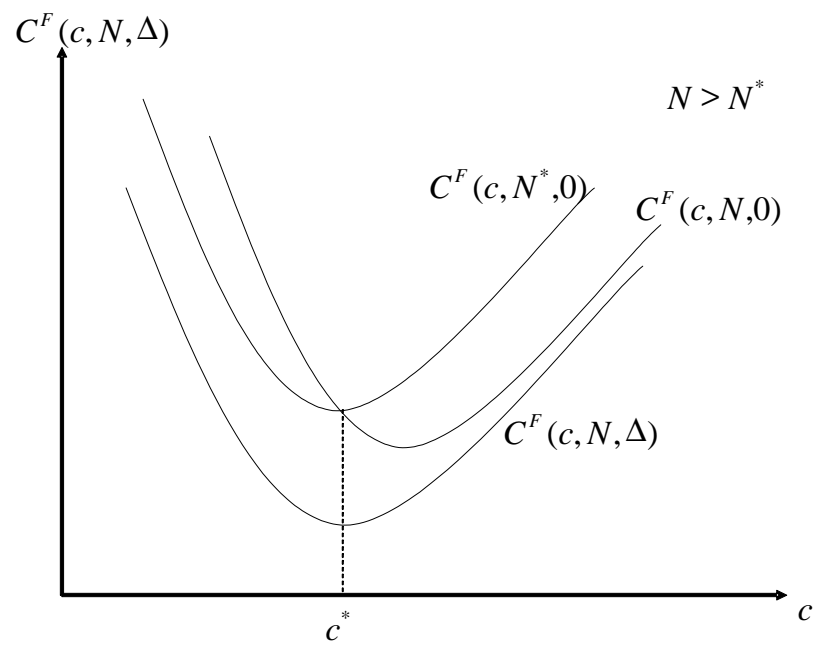

the state of the art defense and the sample size of producers to which the defendant is compared to. For instance, the technologically advancement test necessitates a smaller sample size than the customary practice test. The analysis also suggests that the comparison should not be solely focussed on implementing first best care since it would appear that many combinations of bias and sample size are feasible.

\section{Further considerations}

This paper develops a modelisation of the state of the art defense. From a normative perspective, two considerations require further discussion. First, on the trade off between $\Delta$ and $N$, it seems possible to find arguments in favour of the technologically advancement test. However, the argument necessitates courts to clearly understand the relationship between the bias and the sample size. The second issue refers to the fact that our analysis could be a basis to guide courts applying a state of the art defense. More specifically, the degree of complexity of liability cases have to be correctly adressed by courts.

\subsection{The tradeoff between $\Delta$ and $N$}

From the preceding analysis, we know that raising $N$ increases the firms' responsiveness to the ex post contest (i.e. the state of the art defense). As 
a result all the firms increase care above $c^{*}$. Geometrically, an increase $N$ shifts a firm's expected cost as shown in the Figure (figure 3).

We observe that the true social costs must be raised (since $c>c^{*}$ ). In turn, this must imply that the externality is increased since firms' expected costs are lower. By reducing $\Delta$, the firm's safety costs shift back to the left. With the appropriate reduction, society can induce $c^{*}$. Observe however that it is difficult to develop normative arguments exclusively based on the fact that at the Nash equilibrium $F(\Delta \mid N)<F\left(0 \mid N^{*}\right)$.

There are many other aspects that could influence the comparison between the two legal practices under study:

- First, sampling requires collecting and treating information of different producers' industrial practices and is, thus, a costly activity (note that from a normative perspective, it is irrelevant who carries these costs). ${ }^{16}$ Keeping these costs to a minimum speaks in favor of a small sample and, therefore, a large $\Delta$, i.e. a technologically advancement test.

- Second, evaluating liability rules also demands to consider the impact of damages adjudication on the parties' activity level. In the current situation, we saw earlier that the firms' expected private costs are smaller than the true social costs, $c+p(c) F(\Delta \mid N) L<c+p(c) L$. Consequently, the activity level of the defendant will be excessive compared to the social optimum. In this respect, note that with the customary test $F(0 \mid N)=1 / 2$, whereas with a technologically advancement test $F(\Delta(N) \mid N)>1 / 2$. Thus this second consideration also speaks in favor of defining a defense based on a state of the art argument using the technologically advancement test.

- Third, if one consider the insurance mechanism inherent to civil liability claims, it seems interesting to remark that victims will also be better off under a state of the art defense based on a technologically advancement test. The explanation parallels the foregoing argument; with an increase in $F($.$) firms pay damages more frequently. In other$ words, when state of the art refers to an exceptional safety level, it is more difficult for the defendant to escape liability being at the forefront of technical advancement. So, partisans of tort liability as a mean to compensate parties who suffer loses should prefer a state of the art defense with $F($.$) as close as possible to 1$.

\footnotetext{
${ }^{16}$ It is interesting to note that the ability of the judge to control $N$ is probably different under inquisitorial and adversarial procedures. A discussion of this poinjt goes beyond the scope of this paper.
} 
Under the above considerations, the state of the art defense could satisfy efficiency and equity with a large bias and accordingly a small sample size. In practice, this suggests that the interest of the society could be to define the largest possible $F($.$) , which implies an important bias \Delta$ under a technologically advancement test. In this case, the realization of the first best would be supported by a constraint in term of small $N$.

\subsection{Guiding the courts}

In the paper, we made the hypothesis that courts can collect ex post information on $p(c)$. In practice, this is more complicated. The research of elements about the technological or scientifical conditions of production activities is a complex task. Information could be multidimentional and/or deep investigations could be necessary to find the relevent pieces. In the model, this implies that $\sigma$ needs a special attention. Complex cases are certainly those for which courts applying a state of the art defense have to consider a greater number of elements. In other words, the more a case is complex, the more the variance of the $\varepsilon$ distribution is high. Thus, one can observe that $\sigma$ increases with the degree of complexity. Consequently in the case of a normal distribution (see equation 10), the increasing in $\sigma$ implies to reduce $N$ to implement the first best solution. So, when courts are facing complex situations, the recommendation could be to apply a technologically advancement test further reducing the number of firms with which the defendant is compared to.

\section{Conclusion}

To conclude, our analysis considers two interpretations of the state of the art defense in civil liability claims. It suggests that the customary practice test and the technologically advancement test could be -contrary to the intuitionequivalent in terms of firms' efforts to promote safer technologies. In analytical terms, the reason is that a trade-off exists between the bias introduced by the courts to establish the state of the art relatively to the average level of care and the size of the sample. Of course, it is difficult to determine the optimal combination. However, if the observation of technical characteristics of an industry is difficult for the courts (implying costly and long experts' investigations, it could be better to refer to small samples. In this case, a normative analysis would conclude in favour of the technologically advancement test because it doesn't imply to collect exhaustive informations about firms. Moreover, this system presents advantages in terms of injurers' activity levels and of victims' compensation. 
Finally, the state of the art defense is generally discussed under a strict liability rule. The context which has influenced this choice is of course the one of products liability in most of countries. However, it seems interesting to remark that our main conclusion concerns liability rules in general. In a sens, the problem of the state of the art defense is similar to the definition of a due care standard under a negligence rule. The problem can be easily extended in this way because a due care standard could be define in reference to the current practices of people or to an exceptional level of effort by them.

\section{REFERENCES}

Boyd J. and D. A. Ingberman (1997): "Should "Relative Safety" be a Test of Product Liability?", Journal of Legal Studies, 26(2):433-473.

Brown J. P. (1974): "Product Liability: The Case of an Asset with Random Life", American Economic Review, 64(1): 149-161.

Calfee R. and Craswell J.E. (1986): "Deterrence and Uncertain Legal Standards" (with John E. Calfee), Journal.of Law, Economics \& Organization, vol 2, no 2, 279-303

Landes, W.M. and Posner R. (1981): "The Positive Economic Theory of Tort Law," Georgia Law Review, 15:851-924.

Landes, W.M. and Posner R. (1987): The Economic Structure of Tort Law, Cambridge University Press.

Lazear, E. and S. Rosen (1981): "Rank order tournaments as optimum labor contracts", Journal of Political Economy, 89: 841-861.

Milgrom P. R. (1981): "Good News and Bad News: Representation Theorems and Applications", Bell Journal of Economics, 12( 2): 380-391.

Polinsky, A.M. (1980): "Strict Liability vs. Negligence in a Market Setting," American Economic Review, 70:363-370.

Porter, M. E. (1990): The Competitive Advantage of Nations, The Free Press.

Shavell, S. (1980): "Strict Liability Versus Negligence," Journal of Legal Studies, 9:1-25.

Shavell, S. (1987): Economic Analysis of Accident Law, Harvard University Press.

Spence, M. (1977): "Consumer Misperceptions, Product Failure and Producer Liability", Review of Economic Studies, 44:561-72. 
Viscusi, W. K. and M. J. Moore (1993): "Product Liability, Research and Development, and Innovation," Journal of Political Economy, 101(1): 16184. 


\title{
Documents de travail du BETA
}

\author{
2000-01 Hétérogénéité de travailleurs, dualisme et salaire d'efficience. \\ Francesco DE PALMA, janvier 2000. \\ 2000-02 An Algebraic Index Theorem for Non-smooth Economies. \\ Gaël GIRAUD, janvier 2000. \\ 2000-03 Wage Indexation, Central Bank Independence and the Cost of Disinflation. \\ Giuseppe DIANA, janvier 2000. \\ 2000-04 Une analyse cognitive du concept de « vision entrepreneuriale ». \\ Frédéric CRÉPLET, Babak MEHMANPAZIR, février 2000. \\ 2000-05 Common knowledge and consensus with noisy communication. \\ Frédéric KCESSLER, mars 2000. \\ 2000-06 Sunspots and Incomplete Markets with Real Assets. \\ Nadjette LAGUÉCIR, avril 2000. \\ 2000-07 Common Knowledge and Interactive Behaviors : A Survey. \\ Frédéric KCESSLER, mai 2000. \\ 2000-08 Knowledge and Expertise : Toward a Cognitive and Organisational Duality of the Firm. \\ Frédéric CRÉPLET, Olivier DUPOUËT, Francis KERN, Francis MUNIER, mai 2000. \\ 2000-09 Tie-breaking Rules and Informational Cascades : A Note. \\ Frédéric KGESSLER, Anthony ZIEGELMEYER, juin 2000. \\ 2000-10 SPQR : the Four Approaches to Origin-Destination Matrix Estimation for Consideration by the \\ MYSTIC Research Consortium. \\ Marc GAUDRY, juillet 2000. \\ 2000-11 SNUS-2.5, a Multimoment Analysis of Road Demand, Accidents and their Severity in \\ Germany, 1968-1989. \\ Ulrich BLUM, Marc GAUDRY, juillet 2000. \\ 2000-12 On the Inconsistency of the Ordinary Least Squares Estimator for Spatial Autoregressive \\ Processes. \\ Théophile AZOMAHOU, Agénor LAHATTE, septembre 2000. \\ 2000-13 Turning Box-Cox including Quadratic Forms in Regression. \\ Marc GAUDRY, Ulrich BLUM, Tran LIEM, septembre 2000. \\ 2000-14 Pour une approche dialogique du rôle de l'entrepreneur/managerdans l'évolution des PME : \\ I'ISO comme révélateur ... \\ Frédéric CRÉPLET, Blandine LANOUX, septembre 2000. \\ 2000-15 Diversity of innovative strategy as a source of technological performance. \\ Patrick LLERENA, Vanessa OLTRA, octobre 2000. \\ 2000-16 Can we consider the policy instruments as cyclical substitutes ?
}




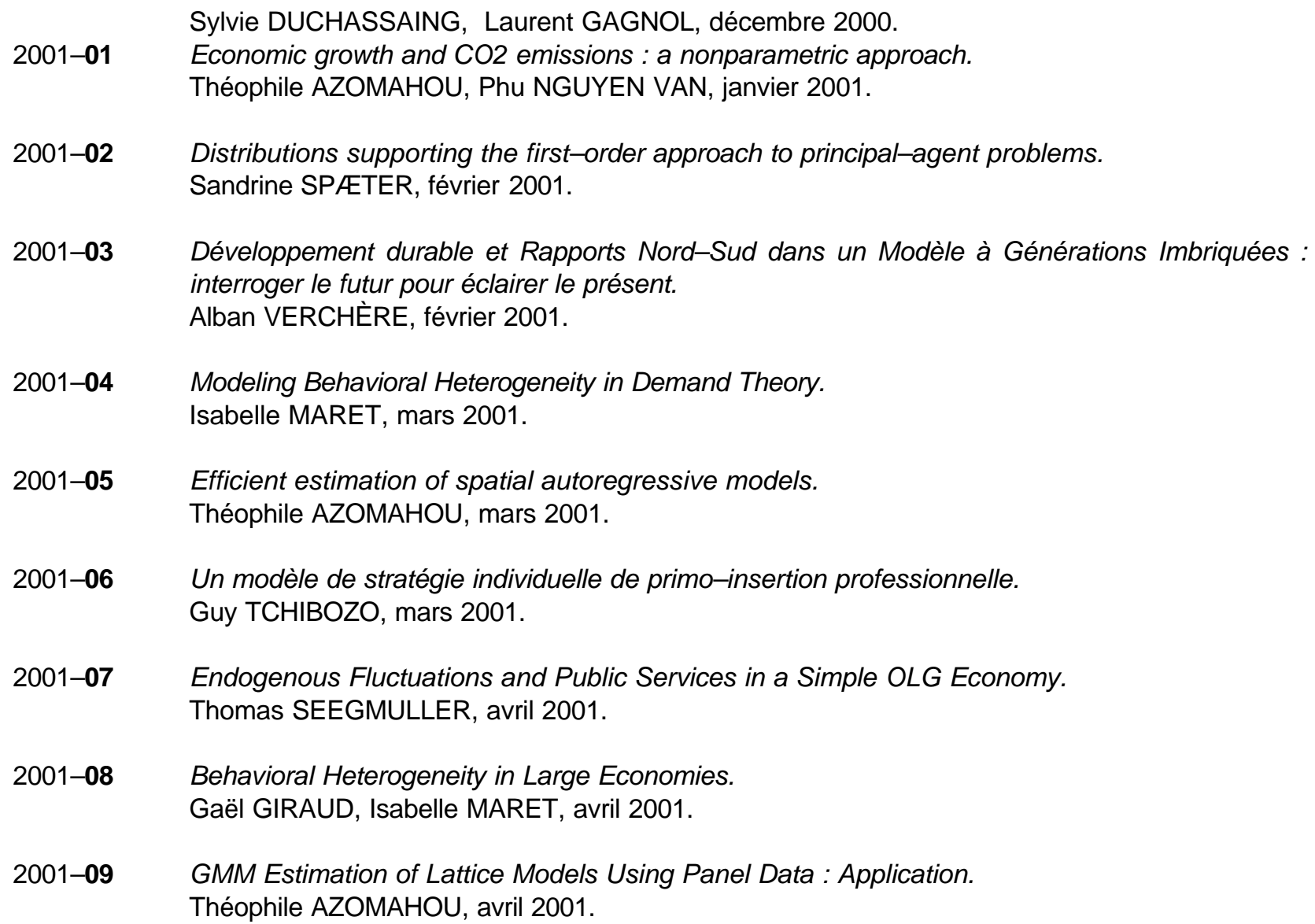

2001-10 Dépendance spatiale sur données de panel : application à la relation Brevets-R\&D au niveau régional. Jalal EL OUARDIGHI, avril 2001.

2001-11 Impact économique régional d'un pôle universitaire : application au cas strasbourgeois. Laurent GAGNOL, Jean-Alain HÉRAUD, mai 2001.

2001-12 Diversity of innovative strategy as a source of technological performance.

Patrick LLERENA, Vanessa OLTRA, mai 2001.

2001-13 La capacité d'innovation dans les regions de l'Union Européenne. Jalal EL OUARDIGHI, juin 2001.

2001-14 Persuasion Games with Higher Order Uncertainty. Frédéric KCESSLER, juin 2001.

2001-15 Analyse empirique des fonctions de production de Bosnie-Herzégovine sur la période 19521989.

Rabija SOMUN, juillet 2001.

2001-16 The Performance of German Firms in the Business-Related Service Sectors : a Dynamic Analysis.

Phu NGUYEN VAN, Ulrich KAISER, François LAISNEY, juillet 2001.

2001-17 Why Central Bank Independence is high and Wage indexation is low. Giuseppe DIANA, septembre 2001.

2001-18 Le mélange des ethnies dans les PME camerounaises: l'émergence d'un modèle d'organisation du travail. 
Raphaël NKAKLEU, octobre 2001.

2001-19 Les déterminants de la GRH des PME camerounaises.

Raphaël NK AKLEU, octobre 2001.

2001-20 Profils d'identité des dirigeants et stratégies de financement dans les PME camerounaises. Raphaël NKAKLEU, octobre 2001.

2001-21 Concurrence Imparfaite, Variabilité du Taux de Marge et Fluctuations Endogènes.

Thomas SEEGMULLER, novembre 2001.

2001-22 Determinants of Environmental and Economic Performance of Firms : An Empirical Analysis of the European Paper Industry.

Théophile AZOMAHOU, Phu NGUYEN VAN et Marcus WAGNER, novembre 2001.

2001-23 The policy mix in a monetary union under alternative policy institutions and asymmetries.

Laurent GAGNOL et Moïse SIDIROPOULOS, décembre 2001.

2001-24 Restrictions on the Autoregressive Parameters of Share Systems with Spatial Dependence. Agénor LAHATTE, décembre 2001.

2002-01 Strategic Knowledge Sharing in Bayesian Games : A General Model. Frédéric KCESSLER, janvier 2002.

2002-02 Strategic Knowledge Sharing in Bayesian Games : Applications.

Frédéric KCESSLER, janvier 2002.

2002-03 Partial Certifiability and Information Precision in a Cournot Game.

Frédéric KCESSLER, janvier 2002.

2002-04 Behavioral Heterogeneity in Large Economies.

Gaël GIRAUD, Isabelle MARET, janvier 2002.

(Version remaniée du Document de Travail n²001-08, avril 2001).

2002-05 Modeling Behavioral Heterogeneity in Demand Theory.

Isabelle MARET, janvier 2002.

(Version remaniée du Document de Travail n²001-04, mars 2001).

2002-06 Déforestation, croissance économique et population : une étude sur données de panel.

Phu NGUYEN VAN, Théophile AZOMAHOU, janvier 2002.

2002-07 Theories of behavior in principal-agent relationships with hidden action.

Claudia KESER, Marc WILLINGER, janvier 2002.

2002-08 Principe de précaution et comportements préventifs des firmes face aux risques environnementaux.

Sandrine SPÆETER, janvier 2002.

2002-09 Endogenous Population and Environmental Quality.

Phu NGUYEN VAN, janvier 2002.

2002-10 Dualité cognitive et organisationnelle de la firme au travers du concept de communauté.

Frédéric CRÉPLET, Olivier DUPOUËT, Francis KERN, Francis MUNIER, février 2002.

2002-11 Comment évaluer l'amélioration du bien-être individuel issue d'une modification de la qualité du service d'élimination des déchets ménagers?

Valentine HEINTZ, février 2002. 
2002-12 The Favorite-Longshot Bias in Sequential Parimutuel Betting with Non-Expected Utility Players.

Frédéric KCESSLER, Anthony ZIEGELMEYER, Marie-Hélène BROIHANNE, février 2002.

2002-13 La sensibilité aux conditions initiales dans les processus individuels de primo-insertion professionnelle : critère et enjeux.

Guy TCHIBOZO, février 2002.

2002-14 Improving the Prevention of Environmental Risks with Convertible Bonds.

André SCHMITT, Sandrine SPFETER, mai 2002.

2002-15 L'altruisme intergénérationnel comme fondement commun de la courbe environnementale à la Kuznets et du développement durable.

Alban VERCHÈRE, mai 2002.

2002-16 Aléa moral et politiques d'audit optimales dans le cadre de la pollution d'origine agricole de l'eau.

Sandrine SPÆETER, Alban VERCHÈRE, juin 2002.

2002-17 Parimutuel Betting under Asymmetric Information.

Frédéric KCESSLER, Anthony ZIEGELMEYER, juin 2002.

2002-18 Pollution as a source of endogenous fluctuations and periodic welfare inequality in OLG economies.

Thomas SEEGMULLER, Alban VERCHÈRE, juin 2002.

2002-19 La demande de grosses coupures et l'économie souterraine.

Gilbert KCENIG, juillet 2002.

2002-20 Efficiency of Nonpoint Source Pollution Instruments with Externality Among Polluters : An Experimental Study.

François COCHARD, Marc WILLINGER, Anastasios XEPAPADEAS, juillet 2002.

2002-21 Taille optimale dans l'industrie du séchage du bois et avantage compétitif du bois-énergie : une modélisation microéconomique.

Alexandre SOKIC, octobre 2002.

2002-22 Modelling Behavioral Heterogeneity.

Gaël GIRAUD, Isabelle MARET, novembre 2002.

2002-23 Le changement organisationnel en PME : quels acteurs pour quels apprentissages ?

Blandine LANOUX, novembre 2002.

2002-24 TECHNOLOGY POLICY AND COOPERATION : An analytical framework for a paradigmatic approach.

Patrick LLERENA, Mireille MATT, novembre 2002.

2003-01 Peut-on parler de délégation dans les PME camerounaises ?

Raphaël NKAKLEU, mars 2003.

2003-02 L'identité organisationnelle et création du capital social : la tontine d'entreprise comme facteur déclenchant dans le contexte africain.

Raphaël NKAKLEU, avril 2003.

2003-03 A semiparametric analysis of determinants of protected area.

Phu NGUYEN VAN, avril 2003. 
2003-04 Strategic Market Games with a Finite Horizon and Incomplete Markets. Gaël GIRAUD et Sonia WEYERS, avril 2003.

2003-05 Exact Homothetic or Cobb-Douglas Behavior Through Aggregation.

Gaël GIRAUD et John K.-H. QUAH, juin 2003.

2003-06 Relativité de la satisfaction dans la vie : une étude sur données de panel.

Théophile AZOMAHOU, Phu NGUYEN VAN, Thi Kim Cuong PHAM, juin 2003.

2003-07 A model of the anchoring effect in dichotomous choice valuation with follow-up. Sandra LECHNER, Anne ROZAN, François LAISNEY, juillet 2003.

2003-08 Central Bank Independence, Speed of Disinflation and the Sacrifice Ratio.

Giuseppe DIANA, Moïse SIDIROPOULOS, juillet 2003.

2003-09 Patents versus ex-post rewards : a new look.

Julien PÉNIN, juillet 2003.

2003-10 Endogenous Spillovers under Cournot Rivalry and Co-opetitive Behaviors.

Isabelle MARET, août 2003.

2003-11 Les propriétés incitatives de l'effet Saint Matthieu dans la compétition académique.

Nicolas CARAYOL, septembre 2003.

2003-12 The 'probleme of problem choice': A model of sequential knowledge production within scientific communities.

Nicolas CARAYOL, Jean-Michel DALLE, septembre 2003.

2003-13 Distribution Dynamics of $\mathrm{CO}_{2}$ Emissions.

Phu NGUYEN VAN, décembre 2003.

2004-01 Utilité relative, politique publique et croissance économique.

Thi Kim Cuong PHAM, janvier 2004.

2004-02 Le management des grands projets de haute technologie vu au travers de la coordination des compétences.

Christophe BELLEVAL, janvier 2004.

2004-03 Pour une approche dialogique du rôle de l'entrepreneur/manager dans l'évolution des PME : I'ISO comme révélateur ...

Frédéric CRÉPLET, Blandine LANOUX, février 2004.

2004-04 Consistent Collusion-Proofness and Correlation in Exchange Economies.

Gaël GIRAUD, Céline ROCHON, février 2004.

2004-05 Generic Efficiency and Collusion-Proofness in Exchange Economies.

Gaël GIRAUD, Céline ROCHON, février 2004.

2004-06 Dualité cognitive et organisationnelle de la firme fondée sur les interactions entre les communautés épistémiques et les communautés de pratique..

Frédéric CRÉPLET, Olivier DUPOUËT, Francis KERN, Francis MUNIER, février 2004.

2004-07 Les Portails d'entreprise: une réponse aux dimensions de l'entreprise "processeur de connaissances ».

Frédéric CRÉPLET, février 2004. 
2004-08 Cumulative Causation and Evolutionary Micro-Founded Technical Change : A Growth Model with Integrated Economies.

Patrick LLERENA, André LORENTZ, février 2004.

2004-09 Les CIFRE : un outil de médiation entre les laboratoires de recherche universitaire et les entreprises.

Rachel LÉVY, avril 2004.

2004-10 On Taxation Pass-Through for a Monopoly Firm.

Rabah AMIR, Isabelle MARET, Michael TROGE, mai 2004.

2004-11 Wealth distribution, endogenous fiscal policy and growth : status-seeking implications.

Thi Kim Cuong PHAM, juin 2004.

2004-12 Semiparametric Analysis of the Regional Convergence Process.

Théophile AZOMAHOU, Jalal EL OUARDIGHI, Phu NGUYEN VAN, Thi Kim Cuong PHAM, Juillet 2004.

2004-13 Les hypothèses de rationalité de l'économie évolutionniste.

Morad DIANI, septembre 2004.

2004-14 Insurance and Financial Hedging of Oil Pollution Risks.

André SCHMITT, Sandrine SPAETER, septembre 2004.

2004-15 Altruisme intergénérationnel, développement durable et équité intergénérationnelle en présence d'agents hétérogènes.

Alban VERCHÈRE, octobre 2004.

2004-16 Du paradoxe libéral-parétien à un concept de métaclassement des préférences.

Herrade IGERSHEIM, novembre 2004.

2004-17 Why do Academic Scientists Engage in Interdisciplinary Research ?

Nicolas CARAYOL, Thuc Uyen NGUYEN THI, décembre 2004.

2005-01 Les collaborations Université Entreprises dans une perspective organisationnelle et cognitive.

Frédéric CRÉPLET, Francis KERN, Véronique SCHAEFFER, janvier 2005.

2005-02 The Exact Insensitivity of Market Budget Shares and the 'Balancing Effect'.

Gaël GIRAUD, Isabelle MARET, janvier 2005.

2005-03 Les modèles de type Mundell-Fleming revisités.

Gilbert KOENIG, janvier 2005.

2005-04 L'État et la cellule familiale sont-ils substituables dans la prise en charge du chômage en Europe ? Une comparaison basée sur le panel européen.

Olivia ECKERT-JAFFE, Isabelle TERRAZ, mars 2005.

2005-05 Environment in an Overlapping Generations Economy with Endogenous Labor Supply : a Dynamic Analysis.

Thomas SEEGMULLER, Alban VERCHÈRE, mars 2005.

2005-06 Is Monetary Union Necessarily Counterproductive?

Giuseppe DIANA, Blandine ZIMMER, mars 2005.

2005-07 Factors Affecting University-Industry R\&D Collaboration : The importance of screening and signalling.

Roberto FONTANA, Aldo GEUNA, Mireille MATT, avril 2005. 
2005-08 Madison-Strasbourg, une analyse comparative de l'enseignement supérieur et de la recherche en France et aux États-Unis à travers l'exemple de deux campus.

Laurent BUISSON, mai 2005.

2005-09 Coordination des négociations salariales en UEM : un rôle majeur pour la BCE.

Blandine ZIMMER, mai 2005.

2005-10 Open knowledge disclosure, incomplete information and collective innovations.

Julien PÉNIN, mai 2005.

2005-11 Science-Technology-Industry Links and the 'European Paradox': Some Notes on the Dynamics of Scientific and Technological Research in Europe.

Giovanni DOSI, Patrick LLERENA, Mauro SYLOS LABINI, juillet 2005.

2005-12 Hedging Strategies and the Financing of the 1992 International Oil Pollution Compensation Fund.

André SCHMITT, Sandrine SPAETER, novembre 2005.

2005-13 Faire émerger la coopération internationale: une approche expérimentale comparée du bilatéralisme et du multilatéralisme.

Stéphane BERTRAND, Kene BOUN MY, Alban VERCHÈRE, novembre 2005.

2005-14 Segregation in Networks.

Giorgio FAGIOLO, Marco VALENTE, Nicolaas J. VRIEND, décembre 2005.

2006-01 Demand and Technology Determinants of Structural Change and Tertiarisation : An InputOutput Structural Decomposition Analysis for four OECD Countries.

Maria SAVONA, André LORENTZ, janvier 2006.

2006-02 A strategic model of complex networks formation.

Nicolas CARAYOL, Pascale ROUX, janvier 2006.

2006-03 Coordination failures in network formation.

Nicolas CARAYOL, Pascale ROUX, Murat YILDIZOGLU, janvier 2006.

2006-04 Real Options Theory for Law Makers.

Marie OBIDZINSKI, Bruno DEFFAINS, janvier 2006.

2006-05 Ressources, compétences et stratégie de la firme: Une discussion de l'opposition entre la vision Porterienne et la vision fondée sur les compétences.

Fernand AMESSE, Arman AVADIKYAN, Patrick COHENDET, janvier 2006.

2006-06 Knowledge Integration and Network Formation.

Müge OZMAN, janvier 2006.

2006-07 Networks and Innovation : A Survey of Empirical Literature.

Müge OZMAN, février 2006.

2006-08 A.K. Sen et J.E. Roemer : une même approche de la responsabilité ? Herrade IGERSHEIM, mars 2006.

2006-09 Efficiency and coordination of fiscal policy in open economies.

Gilbert KOENIG, Irem ZEYNELOGLU, avril 2006.

2006-10 Partial Likelihood Estimation of a Cox Model With Random Effects : an EM Algorithm Based on Penalized Likelihood.

Guillaume HORNY, avril 2006. 
2006-11 Uncertainty of Law and the Legal Process.

Giuseppe DARI-MATTIACCI, Bruno DEFFAINS, avril 2006.

2006-12 Customary versus Technological Advancement Tests.

Bruno DEFFAINS, Dominique DEMOUGIN, avril 2006.

La présente liste ne comprend que les Documents de Travail publiés à partir du fr janvier 2000. La liste complète peut être donnée sur demande.

This list contains the Working Paper writen after January 2000, 1rst. The complet list is available upon request. 